\title{
Consequences of Dental Occlusion Enhancement by Means of Metal Crowns on the Animal Model
}

\begin{abstract}
ANA ISPAS ${ }^{1}$, ANTARINIA CRACIUN¹, LIANA LASCU1, MARCELA ELISABETA BARBINTA PATRASCU2*, MARIANA CONSTANTINIUC ${ }^{1}$ IIuliu Hatieganu University of Medicine and Pharmacy, Department of Prosthodontics, 32 Clinicilor Str., 400006, Cluj-Napoca, Romania

2University of Bucharest, Faculty of Physics, Department of Electricity, Solid-State Physics and Biophysics, 405 Atomistilor Str., 077125, Magurele, Romania

The purpose of this study was to determine whether there is a correlation between induced occlusal trauma and the occurrence of oxidative stress in the hippocampus. Twenty Wistar rats were randomized into three experimental groups and one control group. Animals in the experimental group were cemented modified crowns on molars to induce occlusal trauma in 7, 14 and 30 days. To evaluate the oxidative stress, blood was drawn from the hippocampus at 7, 14 and 30 day intervals. Oxidative stress was evaluated using the following specific tests: determination of plasma malondialdehyde and serum glutathione values. The results of the study demonstrate that malocclusion experienced by raising the vertical dimension in rats resulted in significant reductions in antioxidants and increase level of free radicals.
\end{abstract}

Keywords: occlusal trauma, hipoccampus, free radicals

A traumatic occlusion is often caused by an abnormal contact of the teeth, masticatory system dysfunction and prosthetic or orthodontic treatments that create occlusal interferences [1]. Any prosthetic treatment should be initiated only after a thorough occlusal analysis has been conducted to detect any possible deviations from normal function. In order to prevent traumatic occlusion in the absence of this preprosthetic occlusal preparation, the prosthetic treatment will only perpetuate the abnormal situation and will continue to contribute to the unfavorable evolution [2].

Many studies have reported that occlusal trauma (OT) can cause numerous destructive biological effects on the stomatognathic system, specifically in the pulp tissue, the periodontium, the alveolar bone, the masticatory muscle, the temporo-mandibular joint and even on the central nervous system $[1,3,4]$. The occlusal trauma has effects on the sensitivity and the mode of conduction of neuronal impulses from the dento-alveolar complex to the primary sensitive neurons. Studies have reported that the production of synaptic effector mediators at the level of the primary sensitive neurons and the release of inductive synaptic mediators in the nerve endings, increase during occlusal trauma $[1,5,6]$.

Malocclusion in rats induced by raising of occlusal vertical dimension (OVD) leads to chronic stress. The rats which underwent an occlusion elevation exhibit an inhibitory-type alteration of the hypothalamohypophysarocortico-adrenal feedback mechanism due to reduced receptor affinity for glucocorticoids and for the hypothalamic messenger RNA receptor. The occlusal trauma increases the plasma level of corticosteroids, alters the ability to learn, which is specific to the hippocampus and contributes to the decrease in the number of neurons [7].

The glucocorticoids modify the activity of antioxidant enzymes, in close relation to the cellular energy metabolism both in the brain and in the peripheral tissues. Increased concentrations of glucocorticoids decrease the antioxidant defense capacity in neurons even in the absence of concomitant neurological aggression [8].

The oxidative stress plays an important role in the neuronal death induced by glucocorticoids, and the mechanisms of action of these hormones are extremely extensive. The syntagm of oxidative stress is defined as an imbalance between oxidants and antioxidants, in which oxidants outnumber antioxidants, resulting in displaying destructive and pathogenic potential [9]. During the last decade, how ever, the oxidative stress (OS) effects on living systems have attracted much more attention than before [10].

In many pathological conditions, an acceleration of the formation of reactive oxygen species (ROS) takes place, resulting in an imbalance between the oxidizing factors and the protective antioxidant systems [11]. The unsaturated fatty acids in the cell membrane constitute the main target of the ROS, altering the cell membrane function. Activation of lipid oxidation ROS is detected by determining lipid peroxidase products such as malondialdehyde (MDA).

The defense against the ROS actions is carried out by ways of several mechanisms, including enzymatic and nonenzymatic mechanisms. Glutathione (GSH) is an intracellular enzyme with a major antioxidant role in the removal of peroxides resulting from aerobic metabolism [12].

The purpose of this study was to determine whether there is a correlation between induced occlusal trauma and the occurrence of oxidative stress in the hippocampus. Therefore, MDA and GSH plasma biomarker values were compared.

\section{Experimental part}

The experimental rat model developed at the Biobase of the Physiology Department of I uliu Hatieganu University of Medicine and Pharmacy Cluj-Napoca included 20 white female Wistar rats (mean weight $300 \mathrm{~g}$ ), randomized to four groups $(n=5)$. The animals were accommodated in 
type II $L$ polycarbonate cages, in a room with a constant temperature ( $21.5-23$ degrees) and $65 \%$ relative humidity. The animals were exposed to a standard 12 hours light/ dark cycle. The rats were administered a light diet and water ad libitum.

The research protocol was approved by the Ethics Committee of UMPh Cluj-Napoca and was registered under the number 39/16.

The animals were randomized to four groups as follows:

1- control group

2 -group with occlusal trauma (OT) for a 7-day period

3 - group with occlusal trauma (OT) for a 14-day period

4-group with occlusal trauma (OT) for a 30-day period

Occlusal trauma was induced by placement of $0.5 \mathrm{~mm}$ thick Ni-Cr metal crowns on the mandibular first molar of the right quadrant in 15 animals. The $0.5 \mathrm{~mm}$ thick metal crowns were made in the dental laboratory, taking into consideration the small size of dental crowns for experimental animals. The rats were anesthetized with intramuscular Ketamine $0.3 \mathrm{mg} / \mathrm{g}$ body weight (b. w) and Narcoxyl $0.1 \mathrm{mg} / \mathrm{g} \mathrm{b}$. w. Before placement of the metal crown, the occlusal surface was professionally brushed. The crowns were cemented with dual cement (BisCem).

\section{Evaluation of oxidative stress}

To evaluate the oxidative stress, blood was drawn from the hippocampus at 7, 14 and 30 day intervals. Oxidative stress was evaluated using the following specific tests: determination of plasma malondialdehyde (MDA) and serum glutathione (GSH) values.

\section{Method of dosing malondialdehyde by fluorescence}

The determination of lipid peroxidation by fluorescence is based on the fact that the malondialdehyde resulting from this process forms a fluorescent adduct with the thiobarbituric acid. For dosing, the plasma sample or tissue homogenate is boiled for 1 hour with a solution of $10 \mathrm{mM}$ 2-thiobarbituric acid in $\mathrm{K} 2 \mathrm{HPO}$, $75 \mathrm{mM}$ and $\mathrm{pH} 3$. After rapid cooling, the reaction product is extracted into $n$ butanol. Its concentration is determined in the organic phase after separation by centrifugation. Measurement of emission intensity was done at $534 \mathrm{~nm}$ with a Perkin Elmer spectrofluorimeter, by a synchronous fluorescence technique with a wavelength difference of $14 \mathrm{~nm}$ between excitation and emission $(\Delta \lambda)$. The concentration of malondialdehyde was determined on the basis of a calibration curve made with known concentrations of MDA, processed in the same way. The concentration values are expressed in $\mathrm{nmol} / \mathrm{mL}$ [13].

Glutathione dosing by fluorescence is based on the fact that it forms a fluorescent product with a phthalaldehyde. Determination is performed in serum, plasma and in tissue homogenates.

Basically, a volume of plasma is mixed with 10\% TCA and centrifuged $10 \mathrm{~min}$ after; the supernatant is separated, and $1.7 \mathrm{~mL}$ of $\mathrm{pH} 8$ phosphate buffer and $1 \mathrm{~mL}$ of 0 phthalaldehyde are added.
After 15 min, the emission intensity is measured at 420 $\mathrm{nm}$ at an excitation of $350 \mathrm{~nm}$.

The concentration of glutathione is determined using a calibration curve made with known concentrations of glutathione processed in the same manner. The concentration values are expressed in $\mathrm{nmol} / \mathrm{mL}$ [14].

The statistical analysis of the results was performed using the Anova test for repeated measurements. All values obtained are expressed as mean and standard deviation of the mean. The level of statistical significance was $p<0.05$

\section{Results and discussions}

First of all, we attempted to identify the metallic prosthesis used for the creation of the occlusal trauma, by checking whether the surgical technique was performed correctly or not. We noticed that the metal prosthesis was correctly cemented in all the animals under study. The crowns were cemented with BisCem, which is a selfetching, self-adhesive, dual-cured resin.

Composite luting cements are very important for adhesive cementation in fixed prosthodontics [15]. Adhesive cements are unique due to the achievement of adhesive bonding for both interfaces: dental tissue and restoration material. These cements have been chemically modified to have high shear bond strength and simultaneously adhere to etched dental tissues and metal restorations, which can be noble and non-noble, electrolytic etched or sandblasted [16].

Analyzing specific oxidative stress, we noticed a connection between occlusal trauma, free radical increase, and antioxidant decrease. The study demonstrated that the GSH antioxidant alters its plasma value according to the duration of exposure to occlusal trauma. The results showed that the animals in group 4 had the lowest values when compared to the previous groups 1,2 and 3.

The GSH antioxidant showed a decrease in plasma levels in the experimental animals in comparison to the control group. For group 2 (OT = 7 days), an average of 0.51536500 and $p<0.02$ were recorded. At 14 days after the experiment, for group 3 , the mean was 0.37464460 and $p<0.01$. Values decreased by day 30, for group 4, showing a mean of 0.13718620 and $p<0.037$ (table 1).

Atthe hippocampus level, plasma levels of MDA showed significant differences. Group 2 (OT $=7$ days) showed an average of 0.07724240 and $p<0.02$. Plasma values increased to 0.11151680 after 14 days for group 3. After 30 days, the mean MDA was 0.19346560 and $p<0.05$ for group 4 (table 2).

This study demonstrates the involvement of oxidative stress in the neuronal death induced by occlusal trauma due to chronic stress. We noticed that MDA showed the highest values after a period of 30 days from the beginning of the experiment. The groups with occlusal trauma for 7 days and 14 days, respectively showed higher plasma levels than the control group. Nerve cells are extremely vulnerable to free radicals because the brain has a high turn-over of oxygen, and cell membranes in the central

\begin{tabular}{|l|l|l|l|l|l|}
\hline $\begin{array}{l}\text { Descriptive } \\
\text { statistics }\end{array}$ & $\begin{array}{l}\text { Group 1 } \\
\text { Control }\end{array}$ & $\begin{array}{l}\text { Group 2 } \\
\text { OT =7 days }\end{array}$ & $\begin{array}{l}\text { Group 3 } \\
\text { OT =14 days }\end{array}$ & $\begin{array}{l}\text { Oroup 4 } \\
\text { OT 30 days }\end{array}$ \\
\hline & $\begin{array}{l}\text { The } \\
\text { average }\end{array}$ & 0.84778400 & 0.51536500 & 0.37464460 & 0.13718620 \\
\hline & & & & & \\
\hline & DStd & 0.145433225 & 0.151283962 & 0.1266885550 & 0.072109955 \\
\hline & p & - & 0.019 & 0.011 & 0.037 \\
\hline & & & & & \\
\hline
\end{tabular}

Table 1

PLASMA LEVELS OF THE GSH FROM THE HIPPOCAMPUS 


\begin{tabular}{|c|c|c|c|c|c|c|}
\hline $\begin{array}{l}\text { Descriptive } \\
\text { statistics }\end{array}$ & & $\begin{array}{l}\text { Group } 1 \\
\text { Control }\end{array}$ & $\begin{array}{l}\text { Group } 2 \\
\text { OT }=7 \text { zile }\end{array}$ & $\begin{array}{l}\text { Group } 3 \\
\text { OT }=14 \text { zile }\end{array}$ & $\begin{array}{l}\text { Group } 4 \\
\text { OT }=30 \text { zile }\end{array}$ & $\begin{array}{c}\text { Table } 2 \\
\text { PLASMA LEVELS OF THE MDA FROM }\end{array}$ \\
\hline \multirow[t]{2}{*}{ MDA } & The average & 0.03207840 & 0.07724240 & 0.11151680 & 0.19346560 & THE HIPPOCAMPUS \\
\hline & D std & 0.006243678 & 0.021956447 & $\begin{array}{l}0.039515881 \\
0.019^{---1-}\end{array}$ & 0.053505964 & \\
\hline
\end{tabular}

nervous system are rich in polyunsaturated fatty acids, which constitute the potential target of lipid peroxidation [8]. Increased oxidative action under the influence of occlusal trauma may result from an increase in the production of reactive oxygen species or from a reduction in oxidative capacity.

Exposure to chronic stress affects the survival, proliferation and differentiation rate of young cells. Stress is associated with elevated glucocorticoid levels leading to apoptosis [17]. The presence of glucocorticoids in elevated concentrations decrease the antioxidant defense capacity in neurons. Thus, the current study also reported the decrease in peroxidase glutathione in the hippocampus. Plasma GSH values have been continuously decreasing from the first group to the end of the 30-day experiment.

Statistically significant differences between the experimental groups and the control group with regard to the GSH values suggest the existence of oxidative stress and the appearance of free radicals.

\section{Conclusions}

The results of the current study demonstrate that malocclusion experienced by raising the vertical dimension in rats resulted in significant reductions in antioxidants and increase in free radicals. Additional studies are required in order to clarify the precise mechanisms by which occlusal disharmony exerts its effects on the function of the hippocampus.

\section{References}

1.LIU, H., JIANG, H., WANG, Y., J. Oral Rehabil., 40, no. 2, 2013, p. 130. 2.CERGHIZAN, D., EARAR, K., SCUTARIU, M.M., DIMOFTE, A.R., GRECU, G.P., JANOSI, K., Mat. Plast., 54, no. 3, 2017, p. 557.
3.MORITA, T., HIRABA, K., MATSUNAGA, T., Ito, Y., MAURO, H., KURITA, K., Arch Oral Biol., 66, 2016, p. 66.

4.MORI, D., KATAYAMA, T., MIYAKE, H., FUJIWARA, S., KUBO, K.Y., Neurosci. Lett., 534, 2013, p. 228.

5.ZHU, M.L., LIU, H.C., HAO, Z.Q., DUAN, L.J ., ZHONGHUA KOU QIANG YI XUE ZA ZHI, 39, 2004, p. 421.

6.WOOLF, C.J ., SAFIEH-GAEABEDIAN, B., Ma, Q.P., Neuroscience, 62, no. 2, 1994, p. 327.

7.MORI, D., MIYAKEA, H., MIZUTANIB, K., SHIMPOB, K., SONODAB, S., YAMAMOTOC, T., FUJ IWARA, S., KUBO, K.Y. Arch Oral Biology, 65, 2016, p. 95.

8.MURESAN, A., ORASAN, R., TACHE, T., Stresul oxidativ în procese fiziologice si patologice. Edit. Todesco, Cluj-Napoca, 2006.

9.SIES, H., Redox Biol, 4, 2015, p.180.

10.BARBINTA-PATRASCU, M.E., BADEA, N., MEGHEA, A., J. Optoelectron. Adv. M., 15, no. 5-6, 2013, p. 596.

11.RIEDL, M.A., NEL, A.E., Curr Opin Allergy Clin Immunol., 8, no. 1, 2008, p. 49.

12.ROBERTS, R.A., SMITH, R.A., SAFE, S., SZABO, C., TJ ALKENS, R.B., ROBERTSON, F.M., Toxicology, 276, no. 2, 2010, p. 85.

13.CONTI, M., MORAN, P.C., LEVILLAIN, P., Improved fluorimetric determination of malondialdehyde. Clin.Chem., 37, 1991, p. 1273.

14.HU, M.L., Methods in Enzymology, 233, 1994, p. 380.

15.PATROI, D.N., MOLDOVAN, M., CERNUSCA-MITARIU, I.S., HANCU, V., COMANEANU, R.M., COMAN, C., BARBU, H.M., Mat.Plast., 53, no. 4, 2016, p. 646.

16.PATROI, D.N., MOLDOVEANU, G., HANCU, V., BOTOACA, 0., COMANEANU, R.M., BARBU, H.M., Mat.Plast., 53, no. 1, 2106, p. 215. 17.KATAYAMA, T., MORI, D., MIYAKE, H., FUJIWARA, S., ONO, Y., TAKAHASHI, T., ONOZUKA, M., KUBO, K.Y., Neurosci. Lett., 520, no. 1, 2012, p. 77.

$\overline{\text { Manuscript received:14.08.2018 }}$ 